\title{
The Earnings Smoothing Management Philosophy of BHCs in the SFAS -133 Framework
}

\author{
Veliota Drakopoulou ${ }^{1}, \mathrm{MBA}, \mathrm{PhD}$ \\ ${ }^{1}$ The Forbes School of Business, Ashford University, San Diego, CA, USA \\ Correspondence: Veliota Drakopoulou, 8822 Spectrum Center Blvd, Office 501, San Diego, CA 92123, USA
}

Received: May 24, 2016

Accepted: July 5, 2016

Online Published: July 7, 2016

doi:10.5430/afr.v5n3p64

URL: http://dx.doi.org/10.5430/afr.v5n3p64

\begin{abstract}
Purpose- The main purpose of this paper is to examine whether or not Bank Holding Companies (BHCs) took advantage of SFAS's 133 differential treatment of the changes in the fair value of cash flow hedges to smooth earnings.

Design/methodology/approach- The author used a causal-comparative research design featuring an investigation on the Income Smoothing effects of BHCs' corporate use of derivatives designated as cash flow hedges and discretionary accruals one year after the 2008 amendment of SFAS 133.

Findings- The results of this research showed that SFAS133-Accounting Hedgers had smoother earnings than SFAS133-Compliant Hedgers due to derivative use but did not take advantage of the differential treatment of cash flow hedges to manipulate earnings. This study suggests that hedge accounting rules under SFAS 133 fully determined the hedging behavior of SFAS-Accounting Hedgers. To ascertain the implementation of effective hedges SFAS-Accounting Hedgers captured the benefits of hedge accounting while compromised the economic benefits of hedging in an attempt to manage any associated accounting volatility and smooth earnings.
\end{abstract}

Research limitations/implications- This study extends prior research on corporate risk management activities of BHCs and impacts social change by presenting new evidence on the effects of SFAS 133 cash-flow hedges on earnings smoothing.

Practical implications- The evidence suggests that corporate governance mechanisms affect earnings management since BHCs withhold discretion with respect to the realization of gains and losses from derivative instruments designated as cash flow hedges. This is an indication that BHCs with an intent to achieve smoother earnings as a leading corporate risk management strategy, have a comparative advantage compared to non-financial institutions to apply hedge accounting since they regularly use derivatives and are more experienced with the implementation of SFAS 133.

Originality/value- Although prior studies typically considered derivatives and accruals as substitute proxies in managing reported earnings, the paper's results suggest that the most significant determinant of earnings smoothing is derivative use for SFAS-Accounting Hedgers and information asymmetry for SFAS133-Compliant Hedgers.

Keywords: Derivatives, Accounting for Derivatives and Hedging Activities, Economic Hedges, Fair Value Hedges, Cash Flow Hedges, SFAS 133, Corporate Risk Management, Earnings Volatility, Earnings Smoothing

Paper type-Research Paper

\section{Introduction}

The Financial Accounting Standards Board (FASB) undertaking of the 2008 amendment of Statement of Financial Accounting Standard No. 133 (SFAS 133), Accounting for Derivative Instruments and Hedging Activities was led by the necessity for factual reporting of derivative instruments and hedging activities in the corporate financial statements relative to the overall advantages of the resulting information (SFAS133, 2008, para. 232). Due to the distinctiveness of many derivatives and the virtual newness of many of these instruments, the accounting profession delayed to coincide with the derivatives world. For many years derivatives were off- balance sheet items, meaning that it was difficult, if not impossible, to determine from traditional financial statements what types of derivatives were being used and the effects of those derivative transactions on earnings. The FASB in an attempt to ameliorate the transparency of financial instruments in the financial statements reacted to concerns about the current 
inconsistency between the accounting for cash flow hedges. The concern before the 2008 amendment of SFAS 133 was that companies might have manipulated earnings by taking advantage of the standard's differential treatment of the variations in the fair value of derivatives designated as cash flow hedging instruments to smooth earnings and avoid negative stock valuations (Thapa and Brown, 2005; Park, 2004; Suh, 2007). In the accounting for cash flow hedges the effective portion from the hedging instrument's gain or loss is reported in other comprehensive income while the hedged item's ineffective portion is reported currently in earnings (SFAS 133, para. 30). This deferral mechanism imposes a high correlation between cash flow hedging with deferred revenues (Eckstein, et al., 2008) causing higher or lower earnings quality conditional to the comparative advantage of timely recognition vs. deferral accounting (Zhou, Raulston, \& Sedor, 2009).

Corporate risk management is one of the most critical operations performed by firms in the financial services industry; because risk management has a large impact on the earnings of these firms and affects their competitiveness in the market (Ansari \& Riasi, 2016; Riasi, 2015). This study extends the corporate risk management behavior of Bank Holding Companies (BHCs) in the framework of SFAS 133 (as amended in 2008) by examining whether or not BHCs manipulated the re-classification of the hedged gains/losses on the respective hedged cash flows to increase/decrease income or increase/decrease expenses according to their needs. Smoother earnings can be achieved by benefiting from the deferral mechanism of the gains/losses of cash flow hedges to selectively defer the recognition of forecasted hedged transactions into earnings. Conceptually, hedge accounting for cash flow hedges requires that gains and losses related to the hedged item and the offsetting gains and losses on the hedging instrument to be recognized in earnings in the same accounting period. However, the accounting problem presented by cash flow hedges is that the hedged items (which are future transactions) are not yet recognized in the financial statements. The gain or loss on the hedging instrument that represents effective hedging is recorded as other comprehensive income (OCI) and accumulated in the equity section of the balance sheet as a component of the accumulated other comprehensive income account (AOCI). The amount recorded in AOCI is subsequently reclassified to earnings in the same period in which the hedged transaction affects earnings (Trombely, 2003). Campbell, Downes, and Schwartz (2015) disputed that nearly sixty percent of their sample companies did not provide adequate information on when they will reclassify their cash flow hedges into earnings while the remaining forty percent of the companies made inexplicit disclosures. Hirshleifer and Teoh (2003) debated that investors find it challenging to see when the effective portion of the derivative's gain or loss is reclassified into earnings after the forecasted transaction affects earnings. Makar, Wan, and Alam (2012) shows that future earnings are negatively associated with unrealized gains/losses on cash flow hedges and investors' expectancies, as signaled in stock prices, do not predict this correlation.

Corporate earnings management has attracted much attention in the accounting literature. "Earnings smoothing is a special case of earnings management involving inter-temporal smoothing of reported earnings relative to economic earnings; it attempts to make earnings look less variable over time" (Goel and Thakor, 2003, p. 1). Tucker and Zarowin (2005) documented the importance of managers' use of financial reporting discretion under the flexibility of the current accounting disclosure requirements. Lobo and Zhou (2001) found that corporate disclosures and earnings management were significantly negatively related concluding that firms that disclosed less engaged more in earnings management and vice versa. Tucker et al. (2005) argued that income smoothing improved earnings apprehensiveness when executives used their judgment to announce their evaluation of forthcoming earnings while it made earnings noisier when managers intentionally distorted the earnings numbers.

\section{Hypothesis Development}

The Association for Financial Professionals (2008) confirms that financial statement analysts often disregard the unrealized gains and losses on derivatives appointing non-GAAP performance evaluating metrics to earnings-per-share ratio (EPS) due to the derivatives accounting distortions caused by the differential earning's recognition of cash flow hedges. The earnings-per-share ratio (EPS) is viewed by most BHCs as the key metric for financial analysts (Graham, Harvey, \& Rajgopal, 2005). In the extant accounting literature, there is a prevalent concern that BHCs might take advantage of the non-uniform earnings recognition deriving from the differential treatment of the gains and losses from variations in the fair value of derivatives designated as cash flow hedges to manipulate earnings to achieve earnings smoothing. Graham et al. (2008) found that 300 out of 401 surveyed financial executives would benefit from cash flow hedge accounting to achieve smoother earnings. Zhou et al. (2009) investigated the prominence of SFAS 133 in the banking industry's income statement by examining whether the differential accounting treatment of different categories of hedging activities under SFAS 133 induced opportunistic earnings management behavior and affirmed that BHCs took advantage of the differential accounting treatment of cash flow hedges that delays the recognition of derivative gains/losses to avert earnings decreases. 
Zhang (2009) suggested that companies engaged in more disparaging risk-management behavior after the implementation of SFAS 133, while Couto (2002) suggested that banks with negative or declining earnings might assume imprudent risks in attempting to increase their earnings. Derivatives and accruals act as substitute proxies in managing reported earnings as stated by Hunt et al., (1997), Barton, (2001), and Zarowin, (2002). This study focuses on the earnings smoothing activities of BHCs through the use of discretionary accruals and cash flow hedges. Smoother earnings can be achieved by delaying to report loan losses (Cornett, McNutt, \& Tehranian, 2009; Barton, 2001; Hunt, Moyer, \& Shevlin, 1997; Kanagaretnam, 2000; Kilic, Lobo, Ranasinghe, \& Sivaramakrishnan, 2012; Zarowin, 2002), and/or manipulate the deferral mechanism of the gains/losses of cash flow hedges to artificially inflate reported capital adequacy ratios (Cornett et al., 2009).

The following research question and associated hypotheses were proposed to examine whether or not BHCs experienced Smoother Earnings after the 2008 implementation of SFAS 133:

1. Did BHCs take advantage of SFAS's 133 differential treatment of the changes in the fair value of derivatives designated as cash flow hedges to manipulate earnings to make them smoother?

H10: There was no difference in Earnings Smoothing for SFAS133-Compliant Hedgers and SFAS133-Accounting Hedgers after the 2008 amendment of SFAS 133.

H1a: There was a difference in Earnings Smoothing for SFAS133-Compliant Hedgers and SFAS133-Accounting Hedgers after the 2008 amendment of SFAS 133.

\section{Research Design}

This study reflects a causal-comparative research design featuring an investigation on the Income Smoothing effects of BHCs' corporate use of derivatives designated as cash flow hedges and discretionary accruals one year after the 2008 amendment of SFAS 133. The primary data to be examined in this study are for U.S. BHCs in Peer $1 \& 2$ Groups. The focus of this study is on the largest financial institutions because BHCs in Peer $1 \& 2$ Groups represent the banking industry's derivative activities as a whole which helps avoid sample selection bias. The data from a sample of 167 BHCs were subjected to descriptive, univariate, and multivariate statistical analyses to address the research question and hypothesis and arrive at conclusions as to whether BHCs took advantage of SFAS's 133 differential treatment of the changes in the fair value of derivatives designated as cash flow hedges to smooth earnings.

As per the selected research design, there is a need to select two comparison groups. One group is composed of a sample of BHCs classified as SFAS133-Accounting Hedgers while the other group is composed of BHCs classified as SFAS133-Compliant Hedgers. These two groups were compared to determine the different hedging activities of BHCs. BHCs were classified as SFAS133-Accounting Hedgers when they use only derivatives qualifying for hedge accounting under SFAS 133 comprising those instruments designated as fair value and cash flow hedges. Alternatively, BHCs were classified as SFAS133-Compliant Hedgers when they use both derivative instruments designated as fair value and cash flow hedges under SFAS 133 and economic hedges that do not qualify for hedge accounting under SFAS 133.

To investigate whether or not BHCs took advantage of SFAS's 133 differential treatment of the changes in the fair value of cash flow hedges to manipulate earnings, a univariate comparison between SFAS133-Accounting Hedgers and SFAS133-Compliant Hedgers were performed to test the research question and investigate the differences on the mean value of BHCs perceived earnings smoothing. If the difference in mean value of earnings smoothing between the compliant and accounting hedgers of the sampled BHCs is not statistically significant $(p>0.05)$ as determined by a two-tailed t-test, then earnings smoothing were the same for both of BHCs groups denoting than earnings smoothing was not due to SFAS133-accounting hedges. To further disentangle the effects of SFAS 133 on earnings smoothing caused by cash flow hedges, a paired sample t-test were conducted to compare BHCs mean amount of gains/ losses on derivatives designated as cash flow hedges reclassified from AOCI into income (OCI).

The modified regression model of Singh (2008) (as shown below) were used to test if the corporate-risk management hedging variables of SFAS133-Accounting Hedgers and SFAS133-Compliant Hedgers significantly predicted any Earnings Smoothing, (a) through loan loss provisions (ESmooth) and, (b) through derivative hedging gains (ESmooth1) in 2009 one year after the amendment of SFAS133. ESmooth is used to disentangle the propensity of BHCs to smooth earnings through loan loss provisions which is the ratio of BHCs loan loss provisions to net interest income (Barton, 2001; Laeven, Levin, 2009). In line with the literature, the most widespread proxy for BHCs income smoothing behavior is the loan loss provision which is the largest accrual of BHCs (Cornett, McNutt, \& Tehranian, 2009; Kanagaretnam, 2000; Kilic, Lobo, Ranasinghe, \& Sivaramakrishnan, 2012). As a proxy for income smoothing, 
the ratio of loan loss provisions (LLPs) is adopted, which is the ratio of a BHC's loan loss provision to net interest income used in Laeven and Levin (2009). BHCs corporate governance could influence their earnings management since they maintain the freedom to choose the amount of the loan loss provisions in addition to the realized amount of the hedged gains and losses from derivative instruments. BHCs in periods of low earnings could use earnings management to smooth earnings by overstating capital adequacy ratios, deferring the recording of loan loss provisions and increasing the realization of derivative hedging gains (Cornett et al., 2009). Kilic et al. (2012) using a sample of US BHCs over the period of 1996-2006 found that banks whose income was most likely affected by SFAS 133 increased their reliance on loan loss provisions for income smoothing post-SFAS 133, while the authors did not find evidence of SFAS 133 improving the value relevance of earnings before taxes and provisions.

ESmoothl is used to disentangle the propensity of BHCs to smooth earnings through the deferral mechanism of the gains/losses of cash flow hedges which is the ratio of total notional value of derivatives used as hedging instruments divided by totals assets (Attia, 2012). The ratio of the total notional value of derivatives used as hedging instruments divided by total assets was used to measure any possible differences in earnings smoothing between SFAS133-Compiant Hedgers and SFAS133-Accounting Hedgers. The ratio of notional value of hedging derivatives to total assets can provide advantageous quantitative information about the recognition of derivatives hedging relationships (Attia, 2012; Barton, 2001)., while the loan loss provision ratio is the largest accrual and the most widespread proxy for BHCs income smoothing (Cornet, et al., 2009; Kanagaretnam, 2000; Kilic, et al., 2012). The regression took the following form:

$$
\begin{aligned}
\text { ESmoothit }= & \beta 0+\beta 1 \text { Notionalit }+ \text { EVolit }+\beta 4 \text { FINLEVit }+\beta 5 \text { CapAdeql it }+\beta 6 \text { UNDERCit }+\beta 7 \text { INFOASYit }+ \\
& \beta 8 \text { MNGRiskit }+\beta \text { IIRLibor }+\beta 10 \text { HEDGEINFit }+\beta 11 \text { NETGains }(\text { Losses }) i t+\varepsilon i t
\end{aligned}
$$

Appendix A below presents the definition of control variables that proxy for the hedging incentives of the two

\begin{tabular}{|c|c|c|}
\hline Variable & Construct & Proxy \\
\hline NOTIONAL & Notional Value & Aggregate total notional value of derivative contracts \\
\hline EVol & Earnings Volatility & $\begin{array}{l}\text { The average standard deviation of the ratio of total earnings before } \\
\text { income taxes and loan loss provisions to average total assets }\end{array}$ \\
\hline ESmooth & Earnings Smoothing & The ratio of loan loss provisions to net interest income \\
\hline ESmooth1 & Earnings Smoothing & $\begin{array}{l}\text { The ratio of the total notional value of derivatives used as hedging } \\
\text { instruments divided by total assets }\end{array}$ \\
\hline FINLEV & Financial Distress & $\begin{array}{l}\text { Tier } 1 \text { Leverage ratio defined as Tier } 1 \text { Capital divided by adjusted } \\
\text { quarterly average total assets after certain adjustments }\end{array}$ \\
\hline INFOASY & Information Asymmetry & The logarithm of the number of analysts following the firm each year \\
\hline UNDERC & Underinvestment Cost & $\begin{array}{l}\text { Market-to-book ratio computed as market value per share of common } \\
\text { stock to book value per share }\end{array}$ \\
\hline MNGRisk & $\begin{array}{l}\text { Managerial } \\
\text { Aversion }\end{array}$ & $\begin{array}{l}\text { Ratio of CEOs stock option-based compensation relative to total } \\
\text { compensation }\end{array}$ \\
\hline CapAdeq1 & BHCs Capital Adequacy & $\begin{array}{l}\text { Tier } 1 \text { Capital which is Total Equity Capital minus (plus) accumulated } \\
\text { net gains (losses) on cash flow hedges. }\end{array}$ \\
\hline IRLIBOR & Interest Rate Coefficient & $\begin{array}{l}\text { The absolute value of the estimated coefficient from a regression of } \\
\text { each BHCs monthly stock returns on the monthly percentage change in } \\
\text { LIBOR }\end{array}$ \\
\hline \multirow[t]{2}{*}{ HEDGEINF } & \multirow[t]{2}{*}{ Hedge Ineffectiveness } & $\begin{array}{l}\text { Measures BHCs ineffective portion of the amount of gain (loss) } \\
\text { recognized in income }\end{array}$ \\
\hline & & on derivatives designated as cash flow or fair value hedges \\
\hline \multirow[t]{2}{*}{ NETGain(Loss) } & \multirow[t]{2}{*}{ Economic Hedges } & $\begin{array}{l}\text { Measures both realized and unrealized gains and losses recognized in } \\
\text { income due }\end{array}$ \\
\hline & & to changes in fair value of derivatives designated as economic hedges \\
\hline OCI & $\begin{array}{l}\text { Net Gains(Losses) } \\
\text { reclassified from OCI to } \\
\text { Income }\end{array}$ & $\begin{array}{l}\text { OCI measures the net realized gains/losses reclassified from AOCI into } \\
\text { income on derivatives designated as cash flow hedges }\end{array}$ \\
\hline
\end{tabular}
groups of BHCs. 


\section{Empirical Results for Earnings Smoothing Hypotheses}

\subsection{Descriptive Statistics}

For SFAS133-Accounting Hedgers descriptive results in Table 1 show that earnings smoothing through discretionary accruals and cash flow hedges are much higher in 2009 one year after the 2008 amendment of SFAS 133. Earnings smoothing through discretionally accruals is 0.57 million for 2009 and 0.17 for 2008, indicating that earnings smoothing through loan loss provisions is three times higher in 2009. Earnings smoothing through cash flow hedges is 1.99 million for 2009 and 0.31 million in 2008, indicating that earnings smoothing through cash flow hedges is six times higher in 2009.

For SFAS133- Compliant Hedgers descriptive results in Table 1 show that earnings smoothing through discretionary accruals and cash flow hedges are much higher in 2009 one year after the 2008 amendment of SFAS 133. Earnings smoothing through discretionally accruals is 0.75 million for 2009 and 0.31 for 2008, indicating that earnings smoothing through loan loss provisions is almost three times higher in 2009. Earnings smoothing through cash flow hedges is 0.76 million for 2009 and 0.10 million in 2008, indicating that earnings smoothing through cash flow hedges is almost eight times higher in 2009.

Table 1. Descriptive Stats: Dependent Variables for SFAS 133 AHs \& CHs

\begin{tabular}{|c|c|c|c|c|c|c|c|c|}
\hline & \multicolumn{4}{|c|}{ SFAS-133 Accounting Hedgers } & \multicolumn{4}{|c|}{ SFAS-133 Compliant Hedgers } \\
\hline \multirow[b]{4}{*}{$\mathrm{N}$} & \multirow{2}{*}{$\frac{\text { ESmooth }}{2009}$} & \multicolumn{3}{|c|}{ ESmooth1 ESmooth ESmooth1 } & \multirow{2}{*}{$\begin{array}{l}\text { ESmooth } \\
2009\end{array}$} & \multirow[t]{2}{*}{ ESmooth1 } & \multirow{2}{*}{$\begin{array}{l}\text { ESmooth } \\
2008\end{array}$} & ESmooth1 \\
\hline & & & 2008 & & & & & \\
\hline & \multicolumn{2}{|c|}{ Dependent Variables } & \multicolumn{2}{|c|}{ Dependent Variables } & \multicolumn{2}{|c|}{ Dependent Variables } & \multicolumn{2}{|c|}{ Dependent Variables } \\
\hline & 38 & 38 & 38 & 38 & 24 & 24 & 24 & 24 \\
\hline M & 0.57 & 1.99 & 0.17 & 0.31 & 0.75 & 0.76 & 0.31 & 0.10 \\
\hline SD & 1.55 & 2.21 & 0.56 & 0.41 & 1.49 & 1.18 & 0.94 & 1.65 \\
\hline Min & -0.86 & 0.00 & -0.28 & 0.00 & 0.00 & 0.01 & -0.21 & 0.13 \\
\hline $\operatorname{Max}$ & 1.79 & 7.29 & 3.28 & 0.18 & 2.17 & 4.39 & 0.37 & 5.86 \\
\hline SEM & 0.09 & 0.36 & 0.92 & 0.67 & 0.10 & 0.24 & 0.19 & 0.33 \\
\hline Q1 & 0.22 & 0.03 & 0.10 & 0.52 & 0.46 & 0.05 & 0.20 & 0.38 \\
\hline Mdn & 0.46 & 1.14 & 0.21 & 0.15 & 0.64 & 0.17 & 0.79 & 0.72 \\
\hline Q3 & 0.90 & 3.73 & 1.06 & 0.51 & 1.04 & 0.86 & 0.54 & 0.15 \\
\hline
\end{tabular}

For SFAS133-Accounting Hedgers and SFAS133-Compliant Hedgers the descriptive results show that earnings smoothing through discretionary accruals and cash flow hedges were much higher in 2009 one year after the 2008 amendment of SFAS 133. The results propose that BHCs corporate governance could influence their earnings management since they maintain the freedom to choose the amount of the loan loss provisions in addition to the realized amount of the hedged gains and losses from derivative instruments implying that the use of discretionally accruals and cash flow hedges result in higher earnings smoothing. Dey (2004) advocates that sophisticated investors viewed managers' actions to smooth earnings more as opportunistic rather than informative earnings management concluding that firms with higher institutional investments and more analysts do not manipulate earnings management to smooth their earnings signifying the importance of capital market considerations in managers' reporting decisions.

Descriptive statistics in Table 2 show that SFAS133-Compliant Hedgers did not manipulate the differential treatment of cash flow hedges to smooth earnings since the amount of OCI in 2009 is a gain of 0.14 million, while for 2008 is a gain of 0.10 million which is not a significant difference. 
Table 2. Descriptive Stats: SFAS 133-CHs Classification of Hedging Instruments

\begin{tabular}{|c|c|c|c|c|c|c|}
\hline & \multicolumn{2}{|c|}{$\begin{array}{l}\text { Amount of Gain(Loss) } \\
\text { recognized in OCI on } \\
\text { Derivative }\end{array}$} & \multicolumn{2}{|c|}{$\begin{array}{l}\text { Amount of Gain(Loss) } \\
\text { reclassified from AOCI } \\
\text { into Income }\end{array}$} & \multicolumn{2}{|c|}{$\begin{array}{l}\text { Amount of Gain(Loss) } \\
\text { recognized in Income on } \\
\text { Derivative (Ineffective Portion) }\end{array}$} \\
\hline & \multicolumn{6}{|c|}{ SFAS 133 COMPLIANT HEDGERS (CH) } \\
\hline & 2009 & 2008 & 2009 & 2008 & 2009 & 2008 \\
\hline $\mathrm{N}$ & 38 & 38 & 38 & 38 & 38 & 37 \\
\hline M & 8.490 & 1.079 & 1.438 & 1.0315 & 2.254 & 0.241 \\
\hline SD & 2.890 & 3.265 & 1.193 & 1.863 & 1.056 & 1.848 \\
\hline Min & -5.360 & -8.512 & -3.547 & -8.519 & -6.200 & -9.380 \\
\hline Max & 8.200 & 1.752 & 5.234 & 5.400 & 6.010 & 3.280 \\
\hline SEM & 4.690 & 5.297 & 1.936 & 3.022 & 1.712 & 3.038 \\
\hline Q1 & 0.000 & 0.000 & 0.000 & 0.000 & 0.000 & 0.000 \\
\hline Mdn & 1.940 & 3.500 & 1.750 & 6.250 & 0.000 & 0.000 \\
\hline Q3 & 2.430 & 3.467 & 1.985 & 5.962 & 0.000 & 0.100 \\
\hline
\end{tabular}

In the contrary, descriptive statistics in Table 3 show that SFAS133-Accounting Hedgers did try to manipulate the differential treatment of cash flow hedges to smooth earnings since the amount of OCI in 2009 is a gain of 0.21 million, while for 2008 is a loss of -0.30 million which is a significant difference.

Table 3. Descriptive Stats: SFAS 133-AHs Classification of Hedging Instruments

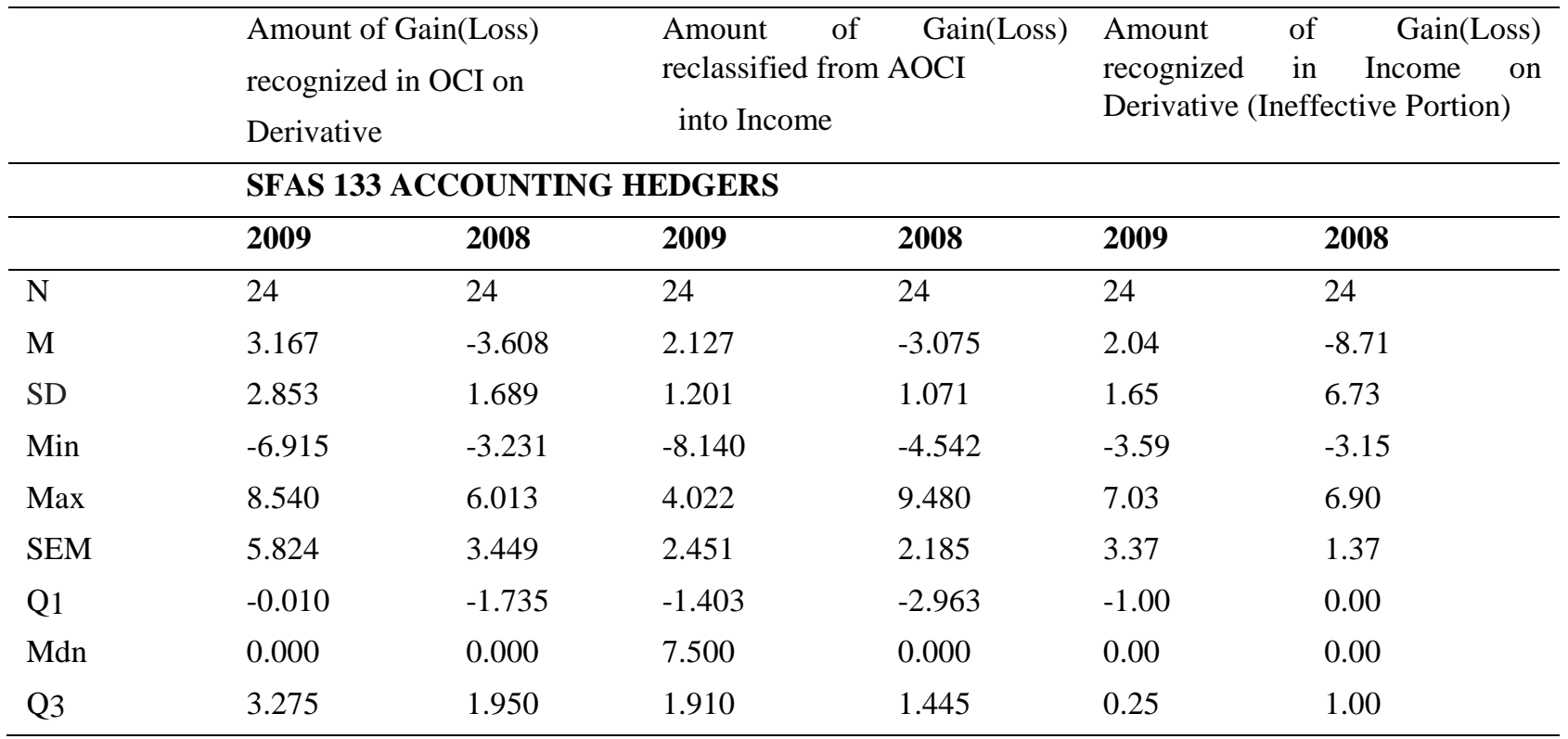

The results suggest that SFAS133-Accounting Hedgers had smoother earnings than SFAS133-Compliant Hedgers due to derivative usage. These findings have been validated in the accounting literature for derivatives and hedging activities under SFAS 133. Papa and Sudarsanam (2010) supported that "the use of derivatives is an alternative way of smoothing earnings" (page 16) and concludes that hedge accounting for cash flow hedges reduces the use of accruals by finding evidence that that SFAS 133 propels the abridged effect of accruals on the use of derivatives. By the same token, Singh (2004) attains that there is a partial substitution relationship between derivative use and accruals concluding that derivatives use affects accruals. Huang, Zhang, Deis \& Moffitt (2009) finds that firm value decreases with the artificial earnings smoothing through accruals and increases with the real earnings smoothing through derivatives use. Attia (2012) showed that derivative use and accounting contravention are earnings smoothing catalysts and that hedging is encouraged in firms with good governance while earnings smoothing is discouraged in these firms. 
Campbell (2012) suggested that companies do not use cash flow hedges to speculate against interest rates, foreign-exchange rates, and commodity prices. The author questions the illicit nature of reporting the cash flow gains and losses in OCI and outside earnings due to their differential treatment under no hedge designation. Cornett et al. (2009) originated that BHCs during periods of low profit can manipulate earnings management to achieve smoother earnings by deferring to report loan loss accruals and escalating the recognition of derivatives instruments hedged gains. Contrary to the belief that earnings smoothing is caused by derivative use Kilic et al. (2012) found that banks whose income is more likely affected by SFAS 133 increase their reliance on loan loss provisions than derivatives and hedging for earnings smoothing and Ahmed, Kilic, and Lobo (2011) argued that the obligatory recognition of hedge ineffectiveness under SFAS 133 moderates the capacity of banks to smooth earnings through derivatives.

\subsection{Paired T- tests}

BHCs during periods of low profit could manipulate earnings management to smooth earnings by deferring to report loan loss accruals and escalating the recognition of derivative instruments hedged gains (Cornett et al., 2009).To disentangle BHCs propensity to smooth earnings through loan loss provisions and/or derivative hedging gains, the ratios of loan loss provisions and total notional value of derivatives were adopted. Following prior literature (Attia, 2012; Barton,2001; Laeven et al., 2009), earnings smoothing was estimated as: (a) the ratio of BHCs loan loss provisions to net interest income (ESmooth), and (b) the ratio of BHCs total notional value of derivatives used as hedging instruments divided by totals assets (ESmoothl). To further disentangle whether smoother earnings is due to derivative usage and/or the differential treatment of the changes in the fair value of cash flow hedging instruments, the amount of BHCs gains/ losses on derivatives designated as cash flow hedges reclassified from AOCI into income $(O C I)$ was examined. Table 4 provides the $\mathrm{t}$ test results of the mean difference between the 2009 and 2008 ESmooth, ESmooth1 and OCI between SFAS133-Compliant Hedgers (CH) and SFAS133-Accounting Hedgers (AH).

Table 4. Results of t-tests for 2008/2009 ESmooth, ESmooth1, and OCI for AH and CH

\begin{tabular}{|c|c|c|c|c|c|c|c|c|c|c|c|}
\hline \multirow[b]{2}{*}{ Outcome } & \multicolumn{2}{|l|}{$\mathrm{AH}$} & \multirow[b]{2}{*}{$\mathrm{n}$} & \multicolumn{2}{|l|}{$\mathrm{CH}$} & \multirow[b]{2}{*}{$\mathrm{n}$} & \multirow[b]{2}{*}{ 95\% CI for Mean Difference } & \multirow[b]{2}{*}{$\mathrm{r}$} & \multirow[b]{2}{*}{$\mathrm{t}$} & \multirow[b]{2}{*}{$p$} & \multirow[b]{2}{*}{$d f$} \\
\hline & $\mathrm{M}$ & SD & & $\mathrm{M}$ & SD & & & & & & \\
\hline ESmooth & 0.56 & 0.54 & 38 & 0.70 & 0.49 & 24 & -0.170 & $.13^{*}$ & 1.30 & .198 & 60 \\
\hline ESmooth1 & 1.98 & 2.21 & 38 & 0.76 & 1.17 & 24 & 1.227 & $.49 *$ & 2.49 & .015 & 60 \\
\hline OCI & 0.40 & 1.71 & 38 & -0.94 & 2.87 & 24 & -0.533 & $.58^{*}$ & -1.76 & .018 & 60 \\
\hline
\end{tabular}

$* \mathrm{p} \geq 0.05$ (two-tailed test). ESmooth: The ratio of loan loss provisions to net interest income; ESmooth1: The ratio of the total notional value of derivatives used as hedging instruments divided by total assets; OCI: Net Gains (Losses) reclassified from OCI to Income. OCI measures the net realized gains/losses reclassified from AOCI into income on derivatives designated as cash flow hedges

The $\mathrm{t}$ test for ESmooth reveals that there is not a significant difference in the 2009 ESmooth of "SFAS133-Compliant Hedgers" $(\mathrm{M}=0.74, \mathrm{SD}=0.49)$ and "SFAS133-Accounting Hedgers" $(\mathrm{M}=0.56, \mathrm{SD}=0.54)$, conditions; $\mathrm{t}(60)=1.30$, $\mathrm{p} \geq 0.05$ (two-tailed test). The $\mathrm{t}$ test for ESmooth1 reveals that there is a significant difference in the 2009 ESmooth1 of "SFAS133-Compliant Hedgers" $(\mathrm{M}=0.76, \mathrm{SD}=1.17)$ and "SFAS133-Accounting Hedgers" $(\mathrm{M}=1.98, \mathrm{SD}=2.21)$, conditions; $\mathrm{t}(60)=-2.49, \mathrm{p} \leq 0.05$ (two-tailed test). The $\mathrm{t}$ test for OCI reveals that there is a significant difference in the 2009 (OCI) of SFAS133-Compliant Hedgers $(\mathrm{M}=-0.94, \mathrm{SD}=2.87)$ and SFAS133-Accounting Hedgers $(\mathrm{M}=0.40$, $\mathrm{SD}=1.71$ ), conditions; $\mathrm{t}(60)=-1.76, \mathrm{p} \leq 0.05$ (two-tailed test).

The outcomes of paired t- tests showed that there is not a significant difference between the 2009 and 2008 earnings smoothing through loan loss provisions for SFAS133-Compliant Hedgers and SFAS133-Accounting Hedgers. In the contrary, the results of paired t tests showed that there is a significant difference between the 2009 and 2008 earnings smoothing through cash flow hedges for SFAS133-Compliant Hedgers and SFAS133-Accounting Hedgers. The t-test results show that earnings smoothing through cash flow hedges is 1.98 million for SFAS133-Accounting Hedgers and 0.76 million for SFAS133-Compliant Hedgers. Earnings smoothing through cash flow hedges is almost three times higher for SFAS133-Accounting Hedgers than SFAS133-Compliant Hedgers.

The results suggest that SFAS133-Accounting Hedgers had smoother earnings than SFAS133-Compliant Hedgers due to use of derivatives while they did not take advantage of the differential treatment of cash flow hedges to manipulate earnings. Smoother earnings can be achieved by benefiting from the deferral mechanism of the gains/losses of cash flow hedges to selectively defer the recognition of forecasted hedged transactions into earnings. Theoretically, hedge accounting entails the hedging instrument gains or losses to be realized in earnings simultaneously with the offsetting losses or gains on the hedged item ascribable to the hedged risk (SFAS133, 2008, 
para. 22-23). The problem presented by hedge accounting for cash flow hedges is that SFAS 133 requires "the effective portion of the gain or loss on the derivative instrument to be reported in accumulated other comprehensive income and reclassified in earnings in the same period during which the hedged forecasted transaction affects earnings" (SFAS133, 2008, para. 18, p. 15), while the mechanism which the hedging gain or loss is reclassified from AOCI to earnings depends on the nature of the hedged item. For example, if the hedged item is a forecasted inventory purchase, the deferred gain or loss from the sale of inventory to customers is reclassified to earnings either by adjusting the inventory purchase amount from the cost of goods sold account or by recognizing the gain or loss as other income or expense (Trombley, 2003).

\subsection{Multiple Regression Analysis}

The Multiple regression model ESmoothit was used to test if the corporate-risk management hedging variables of SFAS133-Accounting Hedgers and SFAS133-Compliant Hedgers significantly predicted any Earnings Smoothing, (a) through loan loss provisions (ESmooth) and, (b) through derivative hedging gains (ESmooth1) in 2009 one year after the amendment of SFAS133. A multiple regression was conducted with the following predictor variables: NOTIONAL, EVol, FINLEV, INFOASY, UNDERC, MNGRisk, CapAdeq1, IRLIBOR, HEDGEIN cash flow, and HEDGEIN $_{\text {fair value }}$, and NETGains/Losses (only for SFAS133-Compliant Hedgers).

Table 5. Multiple regression results for Variables Predicting ESmooth and ESmooth1 for AH and CH

\begin{tabular}{|c|c|c|c|c|c|c|c|c|c|c|c|c|}
\hline & \multicolumn{6}{|c|}{ ESmooth } & \multicolumn{6}{|c|}{ ESmooth1 } \\
\hline & \multicolumn{3}{|c|}{ SFAS 133 AH } & \multicolumn{3}{|c|}{ SFAS $133 \mathrm{CH}$} & \multicolumn{3}{|c|}{ SFAS 133 AH } & \multicolumn{3}{|c|}{ SFAS $133 \mathrm{CH}$} \\
\hline & $\overline{\mathrm{B}}$ & SE B & $\beta$ & $\mathrm{B}$ & SE B & $\beta$ & $\overline{\mathrm{B}}$ & SE B & $\beta$ & $\overline{\mathrm{B}}$ & SE B & $\beta$ \\
\hline FINLEV & -0.055 & 0.0087 & -0.0020 & 0.449 & 0.0049 & 0.0093 & 0.083 & 0.1468 & 0.1232 & -0.294 & 0.1047 & -0.1449 \\
\hline INFOASY & 0.163 & 0.0160 & 0.0118 & -0.004 & 0.0202 & -0.0002 & -0.230 & 0.2710 & -0.6686 & 0.799 & 0.4357 & -1.4299 \\
\hline UNDERC & -0.000 & 0.0130 & -0.0031 & 0.325 & 0.0169 & 0.0265 & -0.125 & 0.2202 & -0.3286 & 0.285 & 0.3644 & 0.5532 \\
\hline MNGRisk & 0.116 & 0.0753 & 0.0322 & -0.073 & 0.0450 & -0.0141 & 0.059 & 0.1274 & 0.6633 & 0.219 & 0.9700 & 1.0099 \\
\hline CapAdeq1 & -0.398 & 0.0050 & -0.0089 & -0.393 & 0.0079 & -0.0118 & 0.107 & 0.8447 & 0.9511 & 0.518 & 0.1708 & 0.3710 \\
\hline IRLIBOR & 0.332 & 0.0048 & 0.0077 & 0.610 & 0.0042 & 0.0096 & 0.039 & 0.8155 & 0.3589 & -0.193 & 0.0900 & -0.0728 \\
\hline HEDGEIN $_{\text {cash flow }}$ & -0.029 & 0.0000 & -0.0000 & -0.551 & 0.0000 & -0.0000 & 0.066 & 0.0014 & 0.0013 & 0.191 & 0.0000 & 0.0000 \\
\hline HEDGEIN $_{\text {fair value }}$ & -0.228 & 0.0000 & -0.0000 & -0.321 & 0.0000 & -0.0000 & -0.188 & 0.0021 & -0.0044 & 0.148 & 0.0001 & 0.0001 \\
\hline OCI & 0.258 & 0.0000 & 0.0000 & 0.196 & 0.0000 & 0.000 & 0.189 & 0.0112 & 0.0241 & 0.159 & 0.0001 & 0.0001 \\
\hline NETGains/Losses & & & & -0.238 & 0.0000 & 0.0000 & 0.083 & 0.1468 & 0.1232 & -0.114 & 0.0023 & -0.0013 \\
\hline
\end{tabular}

* ESmooth AH: $\quad \mathrm{R}^{2}$ of $.336\left(\mathrm{~F}(12,25)=1.06, \mathrm{p}=.4332\right.$; ESmooth $\mathrm{CH}: \mathrm{R}^{2}$ of $.676(\mathrm{~F}(13,10)=1.61, \mathrm{p}=.2289 ; \mathrm{ESmooth} 1 \mathrm{AH}$ :

$\mathrm{R}^{2}$ of $.623(\mathrm{~F}(12,25)=3.44, \mathrm{p}=.0044$; ESmooth1 CH: $\mathrm{R} 2$ of $.705(\mathrm{~F}(13,10)=1.84, \mathrm{p}=.1688$; ESmooth: The ratio of loan loss provisions to net interest income; ESmooth1: The ratio of the total notional value of derivatives used as hedging instruments divided by total assets; FINLEV: Tier 1 Leverage ratio defined as Tier 1 Capital divided by adjusted quarterly average total assets after certain adjustments; INFOASY: The logarithm of the number of analysts following the firm each year; UNDERC: Market-to-book ratio computed as market value per share of common stock to book value per share; MNGRisk: Ratio of CEOs stock option-based compensation relative to total compensation; CapAdeq1: Tier 1 Capital which is Total Equity Capital minus (plus) accumulated net gains (losses) on cash flow hedges; IRLIBOR: The absolute value of the estimated coefficient from a regression of each BHCs monthly stock returns on the monthly percentage change in LIBOR; HEDGEINF: Measures BHCs ineffective portion of the amount of gain (loss) recognized in income on derivatives designated as cash flow or fair value hedges; OCI: OCI measures the net realized gains/losses reclassified from AOCI into income on derivatives designated as cash flow hedges; NETGain(Loss): Measures both realized and unrealized gains and losses recognized in income due to changes in fair value of derivatives designated as economic hedges;

For SFAS133-Accounting Hedgers the prediction of the variables produced a coefficient of determination $\mathrm{R}^{2}$ of .336 $\left(\mathrm{F}_{(12,25)}=1.06, \mathrm{p}=.4332\right)$ for ESmooth. The predictors with the highest VIF coefficient (NOTIONAL, VIF=12.839; 
EVol, VIF=7.446; and ESmooth1, VIF=8.377) were removed from the regression due to multicollinearity. There was no evidence found of a linear regression relationship between the independent variables and earnings smoothing through loan loss provisions for SFAS133-Accounting Hedgers, since the final regression analysis conducted had a low coefficient of determination $\mathrm{R}^{2}=.330, \mathrm{~F}_{(11,26)}=1.16$, and a high $\mathrm{p}$-value $=.3581$.

For SFAS133-Compliant Hedgers the prediction of the variables produced a coefficient of determination $\mathrm{R}^{2}$ of .676 $(\mathrm{F}(13,10)=1.61, \mathrm{p}=.2289)$ for ESmooth. The predictors with the highest VIF coefficient (NOTIONAL, VIF=6.768; $\mathrm{EVol}, \mathrm{VIF}=7.710$; and HEDGEIN fair value, $\mathrm{VIF}=6.911$ ) were removed from the regression due to multicollinearity. There was no evidence found of a linear regression relationship between the independent variables and earnings smoothing through loan loss provisions for SFAS133-Compliant Hedgers, since the final regression analysis conducted had a coefficient of determination $\mathrm{R}^{2}=.625, \mathrm{~F}(10,13)=2.17$, and a high p-value $=.0962$. The results of the regression indicate that there is no linear relationship between the variables and Earnings Smoothing for SFAS133-Accounting Hedgers $\left(\mathrm{R}^{2}=.330, \mathrm{~F}(11,26)=1.16, \mathrm{p}>.005\right)$, while they explained $70 \%$ of the variance in Earnings Smoothing for SFAS133-Compliant Hedgers $\left(\mathrm{R}^{2}=.693, \mathrm{~F}(10,13)=2.94, \mathrm{p}<.005\right)$.

For SFAS133-Accounting Hedgers the prediction of the variables produced a coefficient of determination $\mathrm{R}^{2}$ of .623 $\left(\mathrm{F}_{(12,25)}=3.44, \mathrm{p}=.0044\right)$ with four significant predictors --NOTIONAL, EVol, UNDERC, and IRLIBOR-- for ESmooth1. The strongest predictor was NOTIONAL $(\mathrm{p}=.0022)$, followed by UNDERC $(\mathrm{p}=.0061)$, EVol $(\mathrm{p}$ $=.0211)$, and IRLIBOR $(\mathrm{p}=.0224)$. NOTIONAL $(\beta=0.586, \mathrm{t}=3.420)$ were positively related to ESmooth1, while EVol $(\beta=-0.542, \mathrm{t}=-2.462)$, UNDERC $(\beta=-0.454, \mathrm{t}=-2.993)$, and IRLIBOR $(\beta=-0.407, \mathrm{t}=-2.435)$ were negatively related to ESmooth1. Finally, tests for multicollinearity indicated that a very low level of multicollinearity was present $(\mathrm{VIF}=1.944$ for NOTIONAL, VIF=3.206 for $\mathrm{EVol}, \mathrm{VIF}=1.526$ for UNDERC, and $\mathrm{VIF}=1.851$ for IRLIBOR).

For SFAS133-Compliant Hedgers the prediction of the variables produced a coefficient of determination $\mathrm{R}^{2}$ of .705 $\left(\mathrm{F}_{(13,10)}=1.84, \mathrm{p}=.1688\right)$ for ESmooth1. The predictors with the highest VIF coefficient (NOTIONAL, VIF=6.877; $\mathrm{EVol}, \mathrm{VIF}=7.110$; and HEDGEIN fair value, $\mathrm{VIF}=6.100$ ) were removed from the regression due to multicollinearity. The final regression analysis conducted had a coefficient of determination $\mathrm{R}^{2}$ of $.693\left(\mathrm{~F}_{(10,13)}=2.94, \mathrm{p}=.0360\right)$, with two significant predictors for ESmooth1. The strongest predictor was INFOASY $(\mathrm{p}=.0060)$ followed by CapAdeq1 $(\mathrm{p}=.0490)$. INFOASY $(\beta=-1.429, \mathrm{t}=-3.282)$ was negatively related to ESmooth1, while CapAdeq1 ( $\beta$ $=0.371, \mathrm{t}=2.172)$ was positively related to ESmooth1. Tests for multicollinearity indicated that a low level of multicollinearity was present for INFOASY (VIF =2.515) and CapAdeq1 (VIF=2.408).

The multiple regression analysis showed that the most significant determinant of earnings smoothing for SFAS-Accounting Hedgers is derivative use, while for SFAS133-Compliant Hedgers is information asymmetry. The multiple regression results corroborate with the t-test results that the smoother earnings of SFAS133-Accounting Hedgers are attributable to derivative use while there is no indication that they took advantage of the differential treatment of cash flow hedges to make earnings look smoother. The literature granted some anecdotal evidence on the relationship between derivatives, information asymmetry, and earnings smoothing. Information asymmetry motivates the hedging decisions of firms since they face a higher demand of smoother earnings via derivative activities. Firms with higher percentage of institutional investors and analysts face the burden to hedge their risk exposures with financial derivatives (Brown, 2001). In the United States the derivatives market is controlled by the five largest BHCs which represent $97 \%$ of the total financial industry's notional amount of derivatives (OCC, 2009). This is an indication that BHCs with an intent to achieve smoother earnings as a leading corporate risk management strategy, have a comparative advantage compared to non-financial institutions to apply hedge accounting since they regularly use derivatives and are more experienced with the implementation of SFAS 133.

\section{Conclusion}

The accounting for cash flow hedges assents the effective portion of the hedging instruments' gain or loss to be reported in other comprehensive income while the ineffective portion of the hedged item is reported in earnings (SFAS 133, para. 30). The deferment of cash flow hedging gains and losses signals opportunistic earnings management and lower earnings quality. This study examined the corporate risk management behavior of Bank Holding Companies (BHCs) in the framework of SFAS 133 (as amended in 2008) by assessing whether or not BHCs engineered the classification of the hedged gains/losses on the respective hedged cash flows to manipulate earnings. The research questions were designed to riposte on whether BHCs' benefited from SFAS 133's differential treatment of the changes in the fair value of derivatives designated as cash flow hedges to manipulate earnings and make them smoother. Smoother earnings can be achieved by postponing the recognition of forecasted hedged transactions into earnings due to the deferral of the gains/losses of cash flow hedges allowed by SFAS 133. It was hypothesized that 
there was a difference in earnings smoothing for SFAS133-Compliant Hedgers and SFAS133-Accounting Hedgers after the 2008 amendment of SFAS 133. To test the hypothesis, a regression model was constructed that sought to explain the magnitude of discretionary accounting accruals and cash flow hedging in management of earnings smoothing.

The results showed that earnings smoothing through discretionary accruals and cash flow hedges were much higher in 2009 one year after the 2008 amendment of SFAS 133 for both SFAS133-Accounting Hedgers and SFAS133Compliant Hedgers. Specifically, in 2009 the earnings smoothing through cash flow hedges was six times higher for SFAS133-Accounting Hedgers and eight times higher for SFAS133-Compliant Hedgers. The results insinuate that BHCs' corporate governance through loan loss provisions and cash flow hedges could affect their earnings management. BHCs capacity to inventively select to expanse the use of loan loss provisions as well as the amount of gains or losses reclassified from AOCI into income infers that the use of discretionally accruals and cash flow hedges result in higher earnings smoothing.

The Descriptive statistics and paired t-tests on the classification of hedging instruments for SFAS133 -Compliant Hedgers showed that there was not a significate difference on the amount of OCI between 2008 and 2009 signaling that they did not manipulate the differential treatment of cash flow hedges to smooth earnings. On the contrary, descriptive statistics indicated that SFAS133-Accounting Hedgers had smoother earnings in 2009 due to derivative usage. The multiple regression analysis showed that the most significant determinant of earnings smoothing for SFAS-Accounting Hedgers was derivative use, while for SFAS133-Compliant Hedgers was information asymmetry. These findings have been validated in the accounting literature for derivatives and hedging activities under SFAS 133. Zhou et al. (2009) confirmed that BHCs took advantage of the differential accounting treatment of cash flow hedges to delay the recognition of derivative gains/losses to prevent earnings decreases. Papa et al. (2010) supported that SFAS 133 propels the use of derivatives over accruals. Singh (2004) attains that there is a partial substitution relationship between derivative use and accruals. Huang et al. (2009) affirms that firm value increases with earnings smoothing through derivatives use. Attia (2012) showed that derivative use is an earnings smoothing catalyst.

This study suggests that hedge accounting rules under SFAS 133 fully determined the hedging behavior of SFAS-Accounting Hedgers. SFAS-Accounting Hedgers to ascertain the implementation of effective hedges captured the benefits of hedge accounting while compromised the economic benefits of hedging in an attempt to manage any associated accounting volatility and smooth earnings. The results of descriptive statistics, paired t-tests, and multiple- regression support the earnings smoothing hypothesis and show that SFAS133-Accounting Hedgers had smoother earnings than SFAS133-Compliant Hedgers due to derivative use but did not take advantage of the differential treatment of cash flow hedges to manipulate earnings. This result suggests that corporate governance mechanisms affect earnings management since BHCs withhold discretion with respect to the realization of gains and losses from derivative instruments designated as cash flow hedges. The hedge accounting rules under SFAS 133 fully determine the hedging behavior of SFAS133-Accounting Hedgers since they captured the accounting benefits of hedging while compromising the economic benefits of hedging in an attempt to manage any associated accounting volatility and smooth earnings.

\section{References}

Adkis, C. L., Carter, A. D., \& Simpson, W. G., (2007). Managerial incentives and the use of foreign-exchange derivatives by banks. The Journal of Financial Research, 30(3), 399-413. http://dx.doi.org/10.1111/j.1475-6803.2007.00220.x

Allayannis, G., \& Ofek, E., (2001). Exchange rate exposure, hedging, and the use of foreign currency derivatives. Journal of International Money and Finance, 20(2), 273-296. http://dx.doi.org/10.1016/S0261-5606(00)00050-4

Allayannis, G., \& Weston, P. J., (2001). The use of foreign currency derivatives and firm market value. The Review of Financial Studies, 14, 243. http://dx.doi.org/10.1093/rfs/14.1.243

Al-Shboul, M., \& Alison, S. (2009). The Effects of the Use of Corporate Derivatives on the Foreign Exchange Rate Exposure. Journal of Accounting, Business \& Management, 16(1).

Ansari, A. \& Riasi, A. (2016). Modelling and Evaluating Customer Loyalty Using Neural Networks: Evidence from Startup Insurance Companies. Future Business Journal. 2(1), 15-30. http://dx.doi.org/10.1016/j.fbj.2016.04.001

Attia, M. B. (2012). Accounting income smoothing, hedging and corporate governance. International Journal of Global Business and Management Research, 4(2), 149-163. 
Barnes, R. (2001). Accounting for derivatives and corporate risk management policies. London Business School Accounting Subject Area, (018).

Bedendoa, M., \& Bruno, B. (2009). Credit Risk Transfer Practices in US Commercial Banks.

Brewer, E., Minton A. B., \& Moser, T. J. (2001). Interest rate derivatives and bank lending. Journal of Banking \& Finance, 24(3), 353-379. http://dx.doi.org/10.1016/S0378-4266(99)00041-2

Brown, G. (2001). Managing foreign exchange risk with derivatives. Journal of Financial Economics, 60, 401-448. http://dx.doi.org/10.1016/S0304-405X(01)00049-6

Campbell, J. L. (2012). The fair value of cash flow hedges, future profitability and stock returns. AAA 2010 Financial Accounting and Reporting Section (FARS) Paper. http://dx.doi.org/10.2139/ssrn.1441684

Campell, L. J. (2015). The Fair Value of Cash Flow Hedges, Future Profitability, and Stock Returns. Contemporary Accounting Research, 32(1). http://dx.doi.org/10.1111/1911-3846.12069

Campbell, L. J., Downes, J., and Schwartz, W. (2015). Do sophisticated investors use the information provided by the fair value of cash flow hedges? Review of Accounting Studies. http://dx.doi.org/10.1007/s11142-015-9318-y

Chamberlain, S., Howe, J. S., \& Popper, H. (1997). The exchange rate exposure of US and Japanese banking institutions. Journal of banking \& finance, 21(6), 871-892. http://dx.doi.org/10.1016/S0378-4266(97)00002-2

Choi, J. J., \& Elyasiani, E. (1997). Derivative exposures and the interest rate and exchange rate risks of U.S. banks. Journal of Financial Services Research, 12(2,3), 267-287. http://dx.doi.org/10.1023/A:1007982921374

Cornett, M. M., McNutt, J. J., \& Tehranian, H. (2009). Corporate governance and earnings management at large U.S. bank holding companies. Journal of Corporate Finance, 15(4), 412-430. http://dx.doi.org/10.1016/j.jcorpfin.2009.04.003

Couto, R. L. R. (2002). Framework for the assessment of Bank Earnings. Bank for International Settlements, Financial Stability Institute

Dey, A. (2004). Income smoothing and sophisticated investor preferences. Available at SSRN 571541. http://dx.doi.org/10.2139/ssrn.571541

Eckstein, C., Markelevich, A., \& Reinstein, A. (2008). Accounting for derivative instruments and hedging activities (SFAS No. 133). Review of Accounting and Finance, 7(2), 131-149. http://dx.doi.org/10.1108/14757700810874119

Gilkeson, J. H., \& Smith, S. D. (2006). The impact of derivatives on commercial banks (2000-2004). Working paper, www. bus. ucf. edu.

Goel, M. A. (2003). Why do firms smooth earnings? Journal of Business, 76(1), 151-192. http://dx.doi.org/10.1086/344117

Graham, R. J., Harvey, R. C., \& Rajgopal, S. (2005). The economic implications of corporate financial reporting. Journal of Accounting and Economics, 40(1-3), 3- 73. http://dx.doi.org/10.1016/j.jacceco.2005.01.002

Hagelin, N., \& Pramborg, B. (2004). Hedging foreign exchange exposure: Risk reduction from transaction and translation hedging. Journal of International Financial Management and Accounting, 15(1), 1-21. http://dx.doi.org/10.1111/j.1467- 646X.2004.00099.x

Hirshleifer, D., and Teoh, S. (2003). Limited attention, information disclosure, and financial reporting. Journal of Accounting and Economics, 36, 337-386. http://dx.doi.org/10.1016/j.jacceco.2003.10.002

Hirtle, J. B. (1997). Derivatives, portfolio composition, and bank holding company interest rate risk exposure. Journal of Financial Services Research, 12(2-3), 243- 266. http://dx.doi.org/10.1023/A:1007930904536

Huang, P., Zhang, Y., Deis, R. D., \& Moffitt, S. J., (2009). Does artificial income smoothing and real income smoothing contribute to firm value equivalently? Journal of Banking \& Finance, 33(2), 224-233. http://dx.doi.org/10.1016/j.jbankfin.2008.07.012

Hunt, A., Moyer, S., \& Shevlin, T. (2000). Earnings volatility, earnings management, and equity value. Unpublished working paper. University of Washington.

Junxun, D. (2008). Credit derivatives and risk management banking. Management Science and Engineering, 2(4), 9. Retrieved from http://www.ijmsem.org/ 
Kanagaretnam, K., Lobo, J. G., \& Yang, H. D. (2005). Determinants of signaling by banks through loan loss provisions. Journal of Business Research, 58(3), 312-320. http://dx.doi.org/10.1016/j.jbusres.2003.06.002

Kilic, E., Lobo, G. J., Ranasinghe, T., \& Sivaramakrishnan, K. (2012). The impact of SFAS 133 on income smoothing by banks through loan loss provisions. The Accounting Review, 88(1), 233-260. http://dx.doi.org/10.2308/accr-50264

Laeven, L., \& Levine, R. (2009). Bank governance, regulation and risk taking. Journal of Financial Economics, 93, 259-275. http://dx.doi.org/10.1016/j.jfineco.2008.09.003

Ahmed, A. S., Kilic, E., \& Lobo, G. J. (2011). Effects of SFAS 133 on the risk relevance of accounting measures of banks' derivative exposures. The Accounting Review, 86(3), 769-804. http://dx.doi.org/10.2308/accr.00000033

Lobo, J. G., \& Zhou, J. (2001). Disclosure quality and earnings management. Asia- Pacific Journal of Accounting and Economics, 8(1), 1-20. http://dx.doi.org/10.1080/16081625.2001.10510584

Makar, S., Wang, L., \& Alam, P. (2013). The mixed attribute model in SFAS 133 cash flow hedge accounting: implications for market pricing. Review Of Accounting Studies, 18(1), 66-94. http://dx.doi.org/10.1007/s11142-012-9201-z

Muller, A., \& Verschoor, F. W. (2008). The value-relevance of foreign currency derivatives disclosures. SSRN Working Paper Series, 46. http://dx.doi.org/10.2139/ssrn.1091263

Office of the Comptroller of the Currency. (2009). Interagency advisory on accounting and reporting for commitments to originate and sell mortgage loans. Retrieved on January 10, 2010 from http://www.federalreserve.gov/boarddocs/srletters/2005/SR0510a1.pdf

Pai, P., Curcio, R. J., Thornton Jr., J. H. (2005). Mega Bank Holding Companies' Use of Derivatives for Trading. Proceedings of the March, 2005 Annual Meeting of the Midwest Finance Association.

Papa, V., \& Sudarsanam, P. S., (2010). Impact of US derivatives accounting policy (SFAS 133) on income smoothing choices and disclosure of derivatives related information (Working Paper No. 1826). Retrieved from Cranfield Ceres University website: http://dspace.lib.cranfield.ac.uk/handle/1826/4521

Park, J. (2005). The economic consequences of FAS-133 for bank holding companies. Bank Accounting and Finance, 18(6), 19-26. Retrieved from http://www.inderscience.com/jhome.php?jcode=ijbaaf

Purnanandam, A. (2008). Financial distress and corporate risk management: Theory and evidence. Journal of Financial Economics, 87(3), 706-739. http://dx.doi.org/10.1016/j.jfineco.2007.04.003

Riasi, A. (2015). Competitive Advantages of Shadow Banking Industry: An Analysis Using Porter Diamond Model. Business Management and Strategy, 6(2), 15-27. http://dx.doi.org/10.5296/bms.v6i2.8334

Shiu, Y. M., Moles, P., \& Shin, Y. C. (2010). What motivates banks to use derivatives: Evidence from Taiwan. Journal of Derivatives, 17(4), 67. http://dx.doi.org/10.3905/jod.2010.17.4.067

Singh, A. (2008). The determinants of the decision to use financial derivatives in the lodging industry. Journal of Hospitality \& Tourism Research, 32(4), 423-447. http://dx.doi.org/10.1177/1096348008321364

Sinkey, F. J., \& Carter, A. D. (2000). Evidence on the financial characteristics of banks that do and do not use derivatives. The Quarterly Review of Economics and Finance, 40, 431-449. http://dx.doi.org/10.1016/S1062-9769(00)00050-8

Sun, L., \& Rath, S. (2008). Fundamental determinants, opportunistic behavior and signaling mechanism: an integration of earnings management perspectives. International Review of Business Research Papers, 4(4), 406-420.

Thapa, S., \& Brown, C.L. (2005). The impact of FAS 133: Accounting for derivatives and hedging on financial institution returns. Journal of Commercial Banking and Finance, 4(2), 91-97. Retrieved from http://www.alliedacademies.org/

The Association of Financial Professional. (2008). File Reference Number 1590-100: Proposed Statement of Financial Accounting Standards, Accounting for Hedging Activities, an amendment to Statement No. 133. Comment Letter to FASB. Retrieved on January 10, 2010 from http://www.afponline.org/pub/gr/pdf/AFP_Comment_Letter_to_FASB_on_FAS.p df

Trombley, A. M. (2003). Accounting for derivatives and hedging. New York, NY: McGraw-Hill. 
Tucker, J. W., \& Zarowin, P. A. (2006). Does income smoothing improve earnings informativeness?. The Accounting Review, 81(1), 251-270. http://dx.doi.org/10.2308/accr.2006.81.1.251

Whidbee, A. D., \& Wohar, M. (1999). Derivative activities and managerial incentives in the banking industry. Journal of Corporate Finance, 5, 251-276. http://dx.doi.org/10.1016/S0929-1199(99)00005-X

Zarowin, P. (2002). Does income smoothing make stock prices more informative?. New York University Stern School of Business.

Zhang, H. (2009). Effect of derivative accounting rules on corporate risk management behavior. Journal of Accounting \& Economics, 47(3), 244-264. http://dx.doi.org/10.1016/j.jacceco.2008.11.007

Zhao, F., \& Moser, J. (2009). Use of derivatives and bank holding company interest rate risk. Banking \& Finance Review, 1(1), 51-62. Retrieved from http://www.bankingandfinancereview.com/bfr/index.php/bfr

Zhou, H., Raulston, T., Elliott, W. B., \& Sedor, L. M. (2009). Does Fair Value Accounting for Derivatives Improve Earnings Quality?. Journal of Corporate Finance, 16, 302-319. 